\title{
Winter flock coherence in Willow Tits - who decide what and why
}

\author{
Olav Hogstad
}

Hogstad, O. 2009. Winter flock coherence in Willow Tits - who decide what and why. - Ornis Norvegica 32: 190-201.

Willow Tits Poecile montana (Parus montanus) spend the non-breeding season in mixed-age flocks consisting most often of one social dominant adult mated pair that remain in their territory for the whole of their lives, together with two or four subordinate unrelated first-year birds that have settled after a post-natal dispersal. Since the adults expel the subordinates from the safer parts of the trees in term of predation, juveniles forage in more favourable microhabitats after the flocks temporarily have split into age-specific sub-flocks. However, due to the effect of many eyes, each individual may spend less time scanning for predators and more time foraging when being in a big flock rather than in a small one. To find whether adults or juveniles initiate the splitting into agespecific sub-flocks and set the flock coherence, I followed 6-10 different flocks yearly over nine winters.

Independent of ambient temperature, adult Willow Tits were the first to leave the flock when foraging in the same tree more often than juveniles, whereas juveniles left the flock more often in mild weather $\left(\geq 6^{\circ} \mathrm{C}\right)$ than in cold $\left(<6^{\circ} \mathrm{C}\right)$. When the adult left the flock first, juveniles followed the adult more often in cold than in mild weather, more frequently so within 12 hours than later. After being split into adult and juvenile flocks, the juveniles moved towards and accompanied adults, not the other way round. Juveniles apparently applied for adult company and mostly decided the flock size. When one of the adults left the flock first, its mate followed as the second bird more often than any of the other flock members. In mild weather, when adult and juveniles foraged in separate sub-flocks, dominant adults had no influence on the behaviour of the juveniles that foraged mostly in the upper half of pines, an area supposed to be less exposed to predators. When in company with adults and differing in space use, the juveniles used more time for vigilance and less for foraging than adults, but did not differ in foraging and vigilance time without the company of the alpha pair.

Although company of dominant adults may be disadvantageous for the subordinate juvenile flock members, juveniles capitalize on the greater experience of the adults and provide more time to foraging due to a greater anti-predation benefit due to vigilance reduction because of the effect of many eyes. However, most important: because the habitat is probably saturated with dominant territory owners, flock membership of juveniles is the main route to territory ownership and probably their only chance to breed at the site the following spring. Juvenile Willow Tits that do not succeed in achieving a flock membership during summer and autumn, may leave the area and take part in long-distance movements, settle in a suboptimal habitat or live as floaters that switch among several flocks, alternatives apparently being fatal.

Key words: Winter flock, coherence, Willow Tit, Poecile montana, Parus montanus, social dominance, vigilance behaviour.

Olav Hogstad, Norwegian University of Science and Technology, Section of Natural History, NO-7491 Trondheim, Norway, e-mail address: Olav.Hogstad@vm.ntnu.no

\section{INTRODUCTION}

Many species spend long periods in flocks, the benefits conferred including increased foraging time for each individual because of an improved vigilance level due to scanning activity of more eyes (e.g. Pulliam \& Caraco 1984). Moreover, habitat constraints also may be an important factor affecting flocking, and flock membership may be the main, or even the only, route to territory ownership and future reproduction of juveniles (Woolfenden \& Fitzpatrick 1978, Ekman 1988, 1989, Enoksson 1988, Matthysen 1989, 1990). Most Parine species seem to maintain such a social system in which the birds live in small non-kin winter flocks that remain in exclusive, 
defended areas, e.g. Black-capped Chickadee Poecile atricapillus (Glase 1973), Willow Tit P. montana (Ekman 1979a, Hogstad 1987), Marsh Tit P. palustris (Nilsson \& Smith 1988), Crested Tit Lophophanus cristatus (Ekman 1979a, Lens $\&$ Dhondt 1992). These flocks often consist of one adult mated pair, referred to as the alpha pair, that remains in their territory for the whole of their lives, together with unrelated first-year birds that have settled after a post-natal dispersal. Within such flocks, the males dominate the females and the adults dominate the juveniles of their own sex (Hogstad 1987). Because Willow Tits live in a closed system (Cohen 1971) and the habitat of the species is largely saturated with dominant territory owners (Ekman 1989), the juveniles are apparently forced to stay as subordinate flock members in an occupied territory and hope for ownership, or search for an unoccupied territory elsewhere (Hogstad 1990a, 1999).

Since dominant adult Willow Tits expel subordinates from the safer parts of the trees in terms of predation (Ekman \& Askenmo 1984), juvenile flock members occasionally avoid the adults' company and forage more in favourable sites (Hogstad 1988a). Thus, when energy stress is lessened, e.g. in mild weather or when the birds are provided with extra food, Willow Tit flocks temporarily break up into age-specific sub-flocks (Hogstad 1988a,b). Without the company of dominating adults, it is apparently more profitable for the subordinate Willow Tits to forage than when the adults are present (Hogstad 1988a). When energy requirements increase in cold weather, each individual has to allocate more time to foraging with increased risk of being predated as consequence (e.g. Caraco et al. 1980). Probably because of an increased vigilance level due to the scanning activity of fewer eyes, sub-flocks are rarely observed at low temperatures (Hogstad 1988a). Despite a biased access to contested resources in favour of the adults, the daily survival of subordinate Willow Tits is apparently improved when in company with adults during harsh periods. The fitness of the dominant adults, however, which can forage in more predator-safe microhabitats (Ekman 1986, 1987, Hogstad 1988a), may be less affected by the flock size than the subordinate juveniles. If so, the following predictions can be made: (1) Due to their possibly greater dependence of vigilance towards predators than adults, juvenile flock members should follow the movements of adults in the territory more often than the other way round, i.e. the adult birds should be the first to leave the flock foraging in a common foraging tree more frequently than the juveniles. (2) When the adults leave the flock first, they should do so independent of the ambient temperature, whereas juveniles should leave first more often in mild than in cold weather. (3) Furthermore, juveniles should follow adults more often in cold than in mild weather, and, if the juveniles leave the flock first, the adults should follow accidentally and irrespectively of weather conditions. (4) When the flock has been split, juveniles should reunite with the adults more often than the adults with the juveniles. (5) Since it has been found that the adult male protect his mate against predators and towards attack by higher ranked juvenile male flock members (Hogstad 1992), it seems important for the alpha pair to remain close to each other. Thus it was predicted that if one from the alpha pair leave the flock first, the mate should follow as the second bird before any of the juvenile flock members. (6) Without the company of dominating adults on days with mild weather, juveniles should forage in locations less exposed to predators (upper halves of pine trees; Sparrowhawks Accipiter nisus and small owls take their prey by snatching them from the lower branches, e.g. Hogstad 1988a) and should not differ from adults in time used to vigilance and foraging.

To test these predictions, I studied the flocking behaviour in a colour-marked population of Willow Tits during nine winters.

\section{METHODS}

The study was made in a relatively open, subalpine, mixed forest (altitude 600-750 m) com- 
posed of pine Pinus silvestris and birch Betula odorata in Budal, central Norway $\left(\mathrm{c} .63^{\circ} \mathrm{N}\right)$. The field work was made in two periods, one during November-January 1986-1990, and one during November-February 2000-2005. The study area was about $5 \mathrm{~km}^{2}$ in extent and included annually about 20 territories of Willow Tits.

Prior to the field work, birds from most flocks were individually colour-banded and their sex determined by combination of wing-length and body weight measurements (Haftorn 1982, Hogstad 1987) and their age based on plumage characters (Laaksonen \& Lehikoinen 1976). The size and composition of the flocks were determined on the basis of coherence among individuals, i.e. the proportion of the pooled numbers of observations in which they were seen together in the same flock (see Ekman 1979a). The hierarchical order of the individuals within each flock was determined by observing the outcomes (winners and losers) of agonistic encounters recorded both at feeders placed near the centre of each territory and when the birds were foraging naturally (see Hogstad 1987).

In 1986-1990, the flocks consisted of five or six members, but only flocks of six birds were studied, i.e. one adult mated pair $(\mathrm{M}=$ male, $\mathrm{F}=$ female), two juvenile males $\left(\mathrm{m}_{1}\right.$ and $\left.\mathrm{m}_{2}\right)$ and two juvenile females $\left(f_{1}\right.$ and $f_{2}$ ). Also the juveniles have been considered as pairs $\left(m_{1}-f_{1}\right.$ and $m_{2}-f_{2}$; see Hogstad 1987, Haftorn 1999). In 2000-2005, the number of juveniles in the area seemed lower compared to that of 1986-1990, and the flocks recorded consisted of four to six members. The flocks studied in this period consisted of five or six birds, one mated pair (generally two adults, rarely one adult and one juvenile, see Hogstad 1999), a juvenile pair and one single male or female. The dominance rank within the flocks was $\mathrm{M}>\mathrm{m}_{1}>\mathrm{m}_{2}>\mathrm{F}>\mathrm{f}_{1}>\mathrm{f}_{2}$.

In describing the variation of flock coherence, I recorded which flock member initiated the flock movement and whether other flock members followed or not. Records were only made of flocks when both adults and at least one of the juvenile pairs were in the same tree. The criterion to be the first to leave the flock was that a bird should move more than $10 \mathrm{~m}$ away from their common foraging tree. The birds in the current tree were recorded as «following» when they all moved, within the next one minute, in the same direction as the bird who left the tree first. The birds were recorded as «not following» when some of the other flock members during the next one minute, a) stayed within the current tree, b) were left behind the leaving birds and stayed in neighbouring trees, or c) moved in another direction. The reuniting of the temporarily age-specific sub-flocks was recorded only in 1986-1987 when I carried out a feeding experiment (Hogstad 1988c). Probably because the birds were provided with extra food in 1986-87, the juveniles avoided the company of the dominant adults rather frequently that year, and it was easier to determine which sub-flock moved towards the other.

During the winters 1986-1990, I examined the vigilance behaviour of the birds and recorded the scanning and foraging activity of adult and juvenile birds at different temperature regimes and when the birds stayed in the upper or lower half of the pine trees. Birds with their head up (tip of beak above eye level) or head down were classified as scanning and foraging, respectively. Scanning and foraging are treated as mutually exclusive. The different activities were quantified by using a delayed time point technique (see Ekman 1987). Once an individual had been identified, I started an electronic metronome and recorded the activity of the bird five seconds later. Such a time delay appeared to be sufficient to avoid discovery bias by ensuring that the activity recorded had a chance of being different from the one at first sight (Ekman 1987). To reduce the possibility of statistical dependence between the observations, only one record was made per individual per tree and no more than five records were made of an individual per day.

In the winters 1986-1990, I separated the observations made at ambient temperatures lower than 
$-6^{\circ} \mathrm{C}(\mathrm{T} 1=$ «cold weather» $)$ and $-6^{\circ} \mathrm{C}$ or higher (T2 $=$ «mild weather»). In the winters 2000-2005, I noted the exact temperature and also separated records made before and after 12 hours. I also noted whether it was the adult male or his mate that initiated the flock movement (left the flock first), and whether it was the mate or some of the juveniles that followed as the first «followers». Each flock was recorded only once a day and only rarely more that once a week. In total for the nine winters, 256 records were made of 6-10 different flocks yearly, with 10-76 records each year.

When testing the predictions, one-tailed tests were performed using SPSS 15. Data were analysed using nonparametric tests.

\section{RESULTS}

\section{Coherence}

In accordance with the prediction (1), adult Willow Tits initially left the flock (their common foraging tree) as the first bird more often than juveniles (Table 1). In six of the nine winters, one or both adult birds left the flock first $(n=150)$, in total about $60 \%(58.6 \%)$ of the 256 flocks recorded, i.e. significantly more than juveniles did ( $\mathrm{n}=106$; Mann-Whitney, $\mathrm{z}=-2.01, \mathrm{p}=0.025)$.

No sexual difference was found between the adults as regards the first to leave the flock (male first in 54\% and $42 \%$ at T1 (cold weather, $\mathrm{n}=48$ ) and $\mathrm{T} 2$ (mild weather, $\mathrm{n}=24$ ), respectively; $\chi^{2}=0.75, \mathrm{df}=1$, n.s.).

As predicted (2), one of the adults was the first to leave their common foraging tree, independent of the ambient temperature $(53 \%$ at $\mathrm{T} 1$ vs $47 \%$ at T2; Mann-Whitney, $\mathrm{z}=-0.102$, n.s.), whereas one of the juveniles was the first to leave more often at T2 $(68 \%)$ than T1 (32\%; z=-1.72, p=0 .043; Table 1). Thus, the juvenile flock members left the birds' common foraging tree most frequently in mild weather. The difference in distribution between adults and juveniles in being first to leave at T1 and T2 were significant in the winters 1988-89 $\left(\chi^{2}=5.07, \mathrm{df}=1, \mathrm{p}=0.012\right), 2003-04\left(\chi^{2}=4.29\right.$, $\mathrm{p}=0.019), 2004-05\left(\chi^{2}=6.67, \mathrm{p}=0.006\right)$, and all nine winters combined $\left(\chi^{2}=11.36, \mathrm{p}<0.001\right)$.

The flock size had no effect on whether adults or juveniles left their common foraging tree first (flock size 5: 52\% adults first; flock size 6: $49 \%$ adults first).

When the adult tits left the birds' common foraging tree first, the juveniles, as predicted (3), followed the adults more often in cold (nine of nine winters) than in mild weather (five of nine winters; $\left(\chi^{2}=26.51, \mathrm{df}=1, \mathrm{p}<0.000\right.$; Table 2$)$. Likewise, none of six flocks that I followed continuously for 1-3 hours at ambient temperature lower than $-15^{\circ} \mathrm{C}$ in November 2002 and February 2003 split. On the contrary, when juveniles left the common tree first, the adults followed (52 of 106 cases, $49 \%$ ) or did not follow (54 of 106 cases, $51 \%$ ), irrespective of the ambient temperature $\left(\chi^{2}=0.49, \mathrm{df}=1\right.$, n.s., for all years combined; Table 2). Thus, juvenile Willow Tits seemed more dependent on adults' company in cold than in mild weather, while the adults followed the juveniles randomly, irrespective of temperature.

The mean ambient temperature when adult left first $\left(-7.2{ }^{\circ} \mathrm{C}, \mathrm{n}=58\right)$ differed significantly from the mean temperature when the juveniles left first $\left(-3.0^{\circ} \mathrm{C}, \mathrm{n}=59\right.$; Mann Whitney, $\mathrm{z}=-3.12$, $\mathrm{p}=0.002)$.

When the juveniles followed the adults, they did so more frequently within 12 hours (18 of 18 cases) than later ( 8 of 13 cases; $\chi^{2}=8.25, \mathrm{df}=1$, $\mathrm{p}=0.004)$ in cold weather, while no such tendency was found in mild weather ( 6 of 13 cases before 12 hours and 5 of 14 cases after; $\chi^{2}=0.30$, n.s.).

When temporarily split into adult and juvenile sub-flocks, juveniles were later observed to move towards the adult in eight cases, while the opposite was never observed. This difference departs from random (Fisher's exact test, $\mathrm{p}<0.05$ ). Thus, as predicted (4), juvenile flock members appar- 
Table 1. Number of records of first leaving flock members of adult and juvenile Willow Tits when the flock stayed together in the same tree at ambient temperatures $T 1\left(<-6^{\circ} \mathrm{C}\right)$ and $T 2\left(\geq-6^{\circ} \mathrm{C}\right)$. The study was made during November-January in 1986-1990 and during November-February in 2000-2005.

Adults left first

\begin{tabular}{|c|c|c|c|c|c|c|}
\hline \multirow[b]{2}{*}{ Winter } & & \\
\hline & T1 & T2 & Total & T1 & $\mathbf{T} 2$ & Total \\
\hline 1986-1987 & 6 & 6 & 12 & 1 & 3 & 4 \\
\hline 1987-1988 & 9 & 10 & 19 & 5 & 6 & 11 \\
\hline 1988-1989 & 29 & 17 & 46 & 11 & 19 & 30 \\
\hline $1989-1990$ & 5 & 10 & 15 & 1 & 1 & 2 \\
\hline 1986-1990 & 49 & 43 & 92 & 18 & 29 & 47 \\
\hline $2000-2001$ & 3 & 5 & 8 & 5 & 8 & 13 \\
\hline $2001-2002$ & 4 & 2 & 6 & 1 & 3 & 4 \\
\hline $2002-2003$ & 17 & 17 & 34 & 10 & 22 & 32 \\
\hline $2003-2004$ & 3 & 2 & 5 & 0 & 5 & 5 \\
\hline 2004-2005 & 4 & 1 & 5 & 0 & 5 & 5 \\
\hline $2000-2005$ & 31 & 27 & 58 & 16 & 43 & 59 \\
\hline TOTAL & 80 & 70 & 150 & 34 & 72 & 106 \\
\hline
\end{tabular}

Table 2. Number of records of Willow Tit flock members that followed or did not follow the birds that first left their common foraging tree at ambient temperatures $T 1\left(<-6^{\circ} \mathrm{C}\right)$ and $\mathrm{T} 2\left(\geq-6^{\circ} \mathrm{C}\right)$.

Adults left first Juveniles left first

Juveniles left first

$\begin{array}{lc}\begin{array}{l}\text { Juveniles } \\ \text { followed }\end{array} & \text { Juveniles } \\ \text { did not follow }\end{array}$


ently joined adults more often than the other way round.

When one of the adults left the flock as the first bird, its mate followed as the second one in all cases: males followed his mate in 23 recorded cases, females her mate in 25 cases. Thus, as predicted (5), the alpha members of the flock remained close to each other. Although not significantly so, the juvenile birds also tended to keep together pairwise. When one of the juvenile birds left first, being together with adults or together with juveniles, its «mate» followed as the second bird more often than any of the other flock members. Thus, when $\mathrm{m}_{1}$ left first, $\mathrm{f}_{1}$ followed as the next bird in $70 \%$ of 20 cases, and when $\mathrm{f}_{1}$ left first, $\mathrm{m}_{1}$ was the second bird in $72 \%$ of 25 cases). Correspondingly, when $\mathrm{f}_{2}$ left first, $\mathrm{m}_{2}$ was the next in $65 \%$ of 17 cases recorded and $f_{2}$ followed $m_{2}$ in $57 \%$ of 7 cases. These results may indicate that $m_{1}-f_{1}$ have closer bonds than $m_{2}-f_{2}$.

\section{Space use and vigilance}

The adult and the juvenile flock members differed in use of foraging sites, especially in cold weather (T1): the adults foraged most frequently in the upper halves of the pine trees and the juveniles most frequently in the lower halves. When differing in space use, the two age classes differed significantly in time used to foraging and vigilance (adults $81 \%$ and 19\%, respectively, juveniles 59\% and $41 \% ; \chi^{2}=5.04, \mathrm{df}=1, \mathrm{p}=0.025$; Table 3 ).

In periods of relatively mild weather (T2), the winter flocks occasionally broke up into agespecific sub-flocks. Without the company of the alpha pair, the subordinate juveniles were not influenced by the behaviour of the dominating adults and were frequently observed in the upper halves of pine trees, i.e. a more favourable microhabitat in terms of predation than the lower halves. When not differing from the adults in space use, the juveniles did not differ from the adults in foraging and vigilance time $\left(\chi^{2}=0.17\right.$, n.s.; Table 3). Thus, as predicted (6), the time budgets of the juvenile flocks did not differ from the adults' when unaccompanied by adults.
The adults spent more time foraging at T1 than at T2 $\left(\chi^{2}=3.748, \mathrm{df}=1, \mathrm{p}=0.05\right)$, whereas no such difference was found for the juveniles when foraging in the lower half of the trees (Table 3 ). Thus, the juveniles spent less time foraging than the adults in cold periods, i.e. when the energy requirement is greatest.

Summing up: although the adult mated birds were more often the first to leave the flock and initiate the flock movement within the territory than the juveniles, the latter more frequently accompanied the adults than vice versa, and thus largely decided the flock coherence. The adults obviously were less affected by the flock size than the juveniles because they foraged in safer parts of the trees in term of predation. Despite a biased access to contested resources in disfavour of the juveniles, the daily survival of juveniles probably improved when accompanying adults because of a reduced predation risk due to an increased flock size. The spatial distribution of wintering Willow Tits therefore seems determined by predation risk, whereas social dominance leads to exploitation of unfavourable sites by subordinate juveniles.

\section{DISCUSSION}

Willow Tits live in an environment containing sites more or less exposed for predators. How these sites are used is influenced by social dominance behaviour. Because of their higher rank, the alpha male Willow Tits expel the subordinate juvenile flock members from the upper half of pines, an area supposed to be less exposed to predators (Ekman 1986, Hogstad 1988a,d, Suhonen 1993a). When moving within the territory, independent of ambient temperature, adults were more often the first birds to leave the flock foraging in a common tree more often than juveniles, whereas juveniles left the flock first more often in mild weather (T2 $\left.\geq 6{ }^{\circ} \mathrm{C}\right)$ than in cold $\left(\mathrm{T} 1<6{ }^{\circ} \mathrm{C}\right)$. When an adult initiated the flock movement, i.e. left the flock first, juveniles followed the adult more often in cold than in mild weather. When split into adult 
Table 3. Mean percentage of observations of foraging and scanning by the adult alpha pair and the juvenile members of Willow Tit flocks when staying in upper or lower halves of pine trees at temperatures below -6 ${ }^{\circ} \mathrm{C}\left(\mathrm{T} 1\right.$, cold weather) and $-6^{\circ} \mathrm{C}$ or higher $(T 2$, mild weather $)$. The number combined of foraging and vigilant records is given in parentheses.

(n) Foraging Scanning

\section{Adults and juveniles together}

\section{T1 (cold weather)}

Adults, upper half

Juveniles, lower half

\section{T2 (mild weather)}

Adults, upper half

Juveniles, lower half
81

59

67

59
19

41

33

41

Adults and juveniles in separate subflocks

\section{T2 (mild weather)}

Adults, upper half

Juveniles, upper half
(64)

(58)
66

62
34

38 and juvenile flocks, all records showed that the juveniles that moved towards and reunited with the other flock members. Thus juveniles were obviously dependent of the adults' company in cold weather, whereas adults accidentally followed the juveniles irrespectively of weather conditions. Flock size therefore probably affects the fitness of dominant adults less than that of subordinate juveniles. However, dominants also gain from a bigger flock size because many eyes will detect a predator sooner than few eyes and thus may allow individuals to spend less time scanning and more time feeding. Adult Willow Tit males give alarm calls more frequently than subordinate juveniles (Alatalo \& Helle 1990, Hogstad 1995), whereas subordinate Blackcapped Chickadees give alarm calls sooner than their dominant flock-mates when predators are nearby (Zanette \& Ratcliffe 1994).

That the juveniles followed the adults more frequently within 12 hours than later in cold weather, but not in mild weather, indicates that the energy requirement is greater early in the day than later. This is in accordance with theory that predicts that starvation risk should be minimized by gaining mass at the start of the day, thus insuring against unpredictable food supply later (e.g. McNamara et al. 1994, Pravosudov \& Lucas 2001).

In periods with energetic stress, the flock coherence was high and the flock members apparently provide a greater anti-predation benefit due to vigilance reduction. To counter predation as mortality factor, the birds restricted their use of foraging sites to reduce the predation risk. Dominants, foraging most in the relatively safer sites, therefore profit more in the flocks than the subordinates that used about $20 \%$ more time to vigilance than the adults (Hogstad 1992, present study). The juveniles apparently scanned for predators as well as for the dominant adults when the energy requirement is greatest. Reduced time for foraging increases the juveniles' difficulties in maintaining their daily requirements to meet nocturnal fasting periods of up to 18-19 hours in mid-winter. Each day, the small birds must build up sufficient energy reserves to survive the night in which they must expend energy to survive. The juvenile birds are also more vulnerable than 
adults because they frequently explore areas outside their main territory. Although remaining in their territory, juvenile flock members repeatedly visit surrounding territories to improve their chances of achieving territory ownership in the following spring (Haftorn 1999, Hogstad 1999). Accordingly, the nutritional status of the wintering juveniles is much more constrained energetically than adults (Hogstad 1992). Since dominance status in the winter flock is negatively correlated with the stress-indicating hormone corticosterone (Rohwer \& Wingfield 1981) and juvenile Willow Tits in winter flocks have significantly higher plasma levels of corticosterone than adults (Silverin et al. 1984), subordinates are obviously more stressed than dominant birds Thus, the survival strategies vary with social status and dominants enjoy more benefits than the subordinate juvenile members. In mixed-aged winter flocks, adult Willow Tits (survival rate $=74 \%$ ) survived the winter (December - April) better than juveniles (32\%; Hogstad 1989a; see also Ekman et al. 1981, Ekman 1984, Koivula \& Orell 1988, Lahti et al. 1998).

As the aggressive behaviour of the alpha pair makes flock living less attractive for the subordinate members, juveniles temporarily avoid the adults in periods when the energetic stress is reduced, i.e. in mild weather, and then forage in more favourable microhabitats (Hogstad 1988a, b, present study). A corresponding looser winter flock coherence at ambient temperature above $0{ }^{\circ} \mathrm{C} \mathrm{com-}$ pared to below $0^{\circ} \mathrm{C}$ has also been found for Crested Tit (Lens \& Dhondt 1992) and Bridled Titmouse Baeolophus wollweberi (Christman 2001).

When moving around in the territory, the alpha members of the flock as well as the juvenile malefemale pairs usually remained close to each other (Hogstad 1992, present study). The alpha male protects his mate from both other flock members and predators, particularly when predation risk is high (Hogstad 1992, Suhonen 1993b) and thus secure access for her to preferred resources. By being in close attendance to her mate, the alpha male may increase her nutritional condition and increase the probability of survival during the winter and thus be able to start breeding early on the following spring. Both the alpha pair and the juvenile pairs warned their mates of the presence of predators more frequently if the mate was visible and close by than if it was not visible among the flock members (Hogstad 1995). Warning its mate may therefore be a form of investment in the mate of both the adult and the juvenile pairs (e.g. Hogstad 1995, Haftorn 2000).

It may be speculated that the adults profit on the company of subordinate juveniles by behaving in a feudalistic way and thereby cash in some gain. Willow Tits store several thousands of seeds and larvae each autumn for consumptions during the winter (Haftorn 1956). As it is known that the adults, especially the alpha males in winter flocks may behave as kleptoparasites by stealing food from subordinate flock members (Hogstad 1988b), adult pairs may benefit from retrieving and eating food stored by the juvenile flock members (e.g. Lahti \& Rytkönen 1996, Lahti et al. 1998a, Brodin et al.2001). However, using radioactive food, Brodin \& Ekman (1994) demonstrated that Willow Tits that stored food retrieved about four times as many of its own seeds as did all of its flock members combined. Thus, a cacher enjoyed nearly exclusive access to its own seeds, showing that the cacher has a clear advantage in retrieving its own stored seeds, suggesting that the fitness benefit of storing is selfish.

The company of adults is nevertheless not entirely a disadvantage for a subordinate juvenile Willow Tit. Juveniles are able to capitalize on the greater experience of the adults (cf. Krebs 1973, Ficken \& Witkin 1977), and adults are important in alerting the flock members to the presence of predators, and thus influence the winter survival rate of juveniles (Freeberg 2008, Freeberg \& Harvey 2008). Assuming that all flock members give alarm calls when a predator is discovered, it may be more profitable for the juveniles to remain in a large flock with adults in a microhabitat exposed to predators in periods of energetic 
stress than to be members of a small flock in a less risky microhabitat. Rajala et al. (2003) noted however, after a series with playbacks of conspecific alarm calls that juvenile Willow Tits moved more often, flew longer distances and changed branches more often than did adults and suggested that this juvenile behaviour reflected an increased vulnerability to predators or lack of experience of young birds.

Because Willow Tits live in a closed system (Cohen 1971) and the habitat of the species is largely saturated with dominant territory owners (Hogstad 1999), only a limited number of winter flocks can live in the forest area. Since the flock size is apparently limited (Hogstad 1989b), and, more fledglings are produced than there are possibilities for the juveniles to settle (Hogstad 1990a, 2003), a large number of juveniles does not succeed in achieving permanent flock membership (Hogstad 1990b). Although the species is considered to be stationary, several juvenile Willow Tits leave their natal site and move long distances during late summer and autumn (cf. Ehrenroth 1973).

Juvenile Willow Tits that stay in an area saturated with territory owners and with negligible chances to be a flock member may settle in suboptimal habitats (Hogstad 1987) or live as floaters that switch among several flocks or roam about singly, all alternatives that seem fatal to the juveniles (Ekman 1979a, Hogstad 1989a,b). The floaters, trying to find an opening in a flock, find less food than settled birds (Hogstad 2003) and have small chances to survive the winter (Hogstad 1990b). When among flock members, the floaters behaved submissively, were more vigilant than even the lowest-ranked flock members and maintained a poorer nutritional status than even the lowest ranked flock members during winter (Hogstad $1990 b, 2003)$. When roaming around without dominating flock mates, they may forage in relatively predator-safe sites, but they use much of their time looking out for predators (Hogstad 2003). Floaters disappear in early winter (Ekman 1979a,b, Hogstad 1990b).
The date when a young bird leaves its natal site and begins looking for a flock with an opening, is important for determining flock-joining and subsequent dominance rank in a flock (Nilsson \& Smith 1988, Hogstad 1990a). The potential for breeding at a new site increases for some juveniles that join a flock in hope to increase its dominance status during the winter. Willow Tits start reproduction early in the year. The earlybreeding bird has offspring that disperse early and thus may find a position in the next winter's flock. Flock membership obviously gives them a better nutritional condition through the winter and a chance to breed at the site the following spring.

Winter survival of Willow Tits is apparently related to dominance rank in the flock (Ekman 1987, Hogstad 1987, Koivula \& Orell 1988) and the rank among juveniles seems related to the time they joined a flock (Hogstad 1987, 1990a, Nilsson \& Smith 1988). The juveniles that first joined the adult territory owners became the dominant over the juveniles joining later in the autumn (Hogstad 1987). This suggests that the dominance position is also a function of seniority. A study of skull ossification of juvenile males revealed that the dominant of the males was the oldest in each flock (Hogstad 1990b).

Being a flock member, low-ranked juvenile Willow Tits may remain in a territory together with a dominating adult pair and update their information about the composition and dominance structure of adjacent winter flocks by regularly visiting these territories and attempting to become dominant owners during winter (Hogstad 1999). In doing so, they increase their chances to breed at the site the following spring (cf. Schubert et al. 2007). Subordinate birds will thus rather pay the substantially higher nutritional costs of being a flock member than adopting an even more risky life as a floater. 


\section{SAMMENDRAG}

\section{Størrelse og sammensetning av granmeis- flokker om vinteren - hvem bestemmer hva og hvorfor}

Høst og vinter holder granmeisene sammen i flokker som oftest består av et voksent par, territorieeierne som holder til i territoriet hele livet, og to-fire ungfugler som i løpet av ettersommeren og høsten har slått seg sammen med de voksne. Ungfuglene er sitt første år, er ikke i slekt med hverandre og har bak seg en tid hvor de har streifet omkring etter å ha forlatt foreldrenes territorium. Sammensetningen av flokken er ofte voksen hann-voksen hunn, ung hann $n_{1}$ ung hunn og ung hann - -ung hunn. . Innenfor slike flokker er hannene sosialt dominant over hunnene og de gamle dominerer de unge av samme kjønn. De gamle fuglene s $\varnothing$ ker etter føde i øvre halvdel av trærne og tvinger ungfuglene til å holde seg i nedre halvdel, et område av treet hvor sjansen til å bli tatt av en predator er størst. Flokkene holder ikke sammen hele tiden; de splittes ofte flere ganger om dagen slik at de voksne og de unge farter omkring i separate flokker. For å finne ut hvem som tar initiativet til flokkdelingen og hvorfor de gjør det, ble 6-10 flokker fulgt årlig over ni år i en fjellskog i Budal, Sør-Trøndelag.

De gamle fuglene forlot flokken oftere enn ungfuglene uansett temperatur, mens de unge forlot flokken oftere i mildt vær $\left(\geq 6^{\circ} \mathrm{C}\right)$ enn i kaldt $\left(<6^{0} \mathrm{C}\right)$. Når de gamle dro først, fulgte de unge etter oftere i kaldt enn i mildt vær, også oftere før klokken 12 enn etter. Etter at de gamle og unge hadde fartet hver for seg i kortere eller lengre tid, var det alltid de unge som oppsøkte territorieeierne slik at flokken igjen ble forenet. Ungfuglene var tydeligvis mer avhengige av gamlefuglene enn omvendt og var derfor de som oftest avgjorde flokkstørrelsen. Når en av de gamle dro fra flokken først, fulgte maken straks etter, som oftest før en av de unge. Det samme var ofte tilfellet hvis en av de unge forlot flokken først; maken fulgte som regel etter før noen av de $\emptyset$ vrige flokkmedlemmene.
I kaldt vær var flokken som oftest samlet - de sosialt dominante territorieeierne holdt da til i $\varnothing v$ re del og de subdominante ungfuglene i den mer predatorutsatte nedre del av furutrærne. I tillegg til å bruke tid på å holde utkikk etter predatorer, var de unge også stadig på vakt overfor de dominante fuglene. Ungfuglene var derfor langt mer vaktsomme enn de dominante og fikk rundt $20 \%$ mindre tid til mats $\varnothing \mathrm{k}$. I mildvær, når energibehovet var noe lettere, holdt ungfuglene seg gjerne et stykke unna de dominante og søkte da føde i $\varnothing v$ re halvdel i trærne. I slike tilfelle var det ingen forskjell mellom unge og gamle $\mathrm{i}$ andel tid brukt til å søke etter føde.

Til tross for at de dominante territorieeierne hadde negativ innvirkning på de lavt-rangerte ungfuglene, hadde de unge fordeler av de gamles erfaring og kunne bruke mer tid til fødesøk takket være at flere par øyne raskere oppdager en predator enn få øyne. Det viktigste er imidlertid muligheten til selv å bli territorieeier neste vår. Siden de fleste områder hvor granmeis hekker er mettet med territorieiere, er flokkmedlemskap trolig eneste vei til eget territorium. Unge granmeiser som ikke lykkes i å bli flokkmedlem, må enten trekke ut av området, slå seg ned i et mindre optimalt område eller friste skjebnen som «flyter», det vil si farte rundt i håp om å oppnå flokkmedlemskap. Ingen av disse valgene har vist seg å være vellykket.

\section{REFERENCES}

Alatalo, R.V. \& Helle, P. 1990. Alarm calling by individual Willow Tits Parus montanus. - Anim. Behav. 40: 437-442.

Brodin, A. \& Ekman, J. 1994. Benefits of food hoarding. - Nature 372: 510.

Brodin, A., Lundborg, K. \& Clark, C. 2001. The effect of dominance on food hoarding - a game theoretical model. - Am. Nat. 157: 66-75.

Caraco, T., Martindale, S. \& Whittam, T.S. 1980. An empirical demonstration of risk-sensitive foraging preferences. - Anim. Behav. 28: 820-830. 
Christman, B.J. 2001. Low flock coherence in mild winters leads to a lack of subordination costs in Bridled Titmouse foraging groups. - Ibis 143: 617-626.

Cohen, J.E. 1971. Casual Groups of Monkeys and Men. Cambridge, Harvard University Press.

Ehrenroth, B. 1973. Studies on migration movements of the Willow Tit Parus montanus borealis Selys-Longchamps. - Ornis Scand. 4: 87-96.

Ekman, J. 1979a. Coherence, composition and territories of winter social groups of the Willow Tit Parus montanus and the Crested Tit $P$. cristatus. - Ornis Scand. 10: 56-68.

Ekman, J. 1979b. Non-territorial willow tits Parus montanus de Selys-Longchamps in late summer and early autumn. - Ornis Scand. 10: 262-267.

Ekman, J. 1984. Density-dependent seasonal mortality and population fluctuations of the temperatezone Willow Tit (Parus montanus). - J. Anim. Ecol. 53: 119-134.

Ekman, J. 1986. Tree use and predator vulnerability of wintering passerines. - Ornis Scand. 17: 261-267.

Ekman, J. 1987. Exposure time use in Willow Tit flocks; the cost of subordination. - Anim. Behav. 35: 445-452.

Ekman, J. 1988. Subordination costs and group territoriality in wintering Willow Tits. - Proc. XIX Internatl. Ornithol. Congr. 2373-2381.

Ekman, J. 1989. Ecology of non-breeding social systems of Parus. - Wilson Bull. 101: 263-288.

Ekman, J., Cederholm, G. \& Askenmo, C. 1981. Spacing and survival in winter groups of Willow Tit Parus montanus and Crested Tit P. cristatus - a removal study. - J. Anim. Ecol. 50: 1-9.

Ekman, J. \& Askenmo, C. 1984. Social rank and habitat use in Willow Tit groups. - Anim. Behav. 32: 508-514.

Enoksson, B. 1988. Prospective resource defense and its consequences in the Nuthatch Sitta europaea $\mathrm{L}$. PhD thesis, Uppsala, Sweden.

Ficken, M.S. \& Witkin, S.R. 1977. Responses of Black-capped Chickadees to predators. - Auk 94: 156-157.

Freeberg, T.M. 2008. Complexity in the chick-adee call of Carolina Chickadees (Poecile carolinensis): associations of context and signaller behaviour to call structure. - Auk 125: 896-907.
Freeberg, T.M. \& Harvey, E.M. 2008. Group size and social interactions are associated with calling behaviour in Carolina chickadees (Poecile carolinensis). - J. Comparative Psychology 122: 312-318.

Glase, J.C. 1973. Ecology of social organization in the Black-capped Chickadee. - Living Bird 12: 235-267.

Haftorn, S. 1956. Contribution to the food biology of tits, especially about storing of surplus food, Part III, the Willow Tit Parus atricapillus L. - Kgl. Norske Vidensk. Selsk Skr. 3: 1-79.

Haftorn, S. 1982. Variation in the body measurements of the Willow Tit Parus montanus, together with a method for sexing live birds and data on the degree of shrinkage in size after skinning. - Fauna Norv. Ser. C, Cinclus 5: 16-26.

Haftorn, S. 1999. Flock formation, flock size and flock persistence in the Willow Tit Parus montanus. - Ornis Fennica 76: 49-63.

Haftorn, S. 2000. Contexts and possible functions of alarm calling in the Willow Tit, Parus montanus; the principle of «better safe than sorry». - Behaviour 137: 437-449.

Hogstad, O. 1987. Social rank in winter flocks of Willow Tits Parus montanus. - Ibis 129: 1-9.

Hogstad, O. 1988a. Rank-related resource access in winter flocks of Willow Tits Parus montanus. - Ornis Scand. 19: 169-174.

Hogstad, O. 1988b. Social rank and antipredator behaviour of Willow Tits Parus montanus in winter flocks. - Ibis 130: 45-56.

Hogstad, O. 1988c. The influence of energy stress on social organization and behaviour of Willow Tits Parus montanus. - Fauna norv. Ser. C, Cinclus 11: 89-94.

Hogstad, O. 1988d. Advantages of social foraging of Willow Tits Parus montanus. - Ibis 130: 275-283.

Hogstad, O. 1989a. Subordination in mixed-age bird flocks - a removal study. - Ibis 131: 128-134.

Hogstad, O. 1989b. The role of juvenile Willow Tits, Parus montanus, in the regulation of winter flock size: an experimental study. - Anim. Behav. 38: 920-925.

Hogstad, O. 1990a. Dispersal date and settlement of juvenile Willow Tits Parus montanus in winter flocks. - Fauna norvegica, Ser. C, Cinclus 13: 49-55. 
Hogstad, O. 1990b. Winter floaters in Willow Tits, Parus montanus: a matter of choice or making the best of a bad situation. Pp. 415421 in Population Biology of Passerine Birds, an Integrated Approach (Blondel, A., Gosler, A., Lebreton, J.D. \& McCleery, R. Eds.). Berlin, Springer-Verlag.

Hogstad, O. 1992. Mate protection in alpha pairs of wintering Willow Tits, Parus montanus. Anim. Behav. 43: 323-328.

Hogstad, O. 1995. Alarm calling by Willow Tits, Parus montanus, as mate investment. - Anim. Behav. 49: 221-225.

Hogstad, O. 1999. Territory acquisition during winter by juvenile Willow Tits Parus montanus. Ibis 141: 615-620.

Hogstad, O. 2003. Strained energy budget of winter floaters in the Willow Tit as indicated by ptilochronology. - Ibis 145 (online), E19-E23.

Koivula, K. \& Orell, M. 1988. Social rank and winter survival in the Willow Tit Parus montanus. - Ornis Fennica 65: 114-120.

Krebs, J.R. 1973. Social learning and the significance of mixed-species flocks of chickadees (Parus spp). - Can. J. Zool. 51: 1275-1288.

Laaksonen, M. \& Lehikoinen, E. 1976. Age determinations of Willow and Crested Tit Parus montanus and P. cristatus. - Ornis Fennica 53: 9-14.

Lahti, K. \& Rytkönen, S. 1996. Presence of conspecific, time of day and age affect Willow Tit hoarding. - Anim. Behav. 52: 631-636.

Lahti, K., Orell, M., Rytkönen, S. \& Koivula, K. 1998a. Time and food dependence in Willow Tit winter survival. - Ecology 79: 2904-2916.

Lens, L.\& Dhondt, A.A. 1992. Variation in coherence of Crested Tit winter flocks: an example of multivariate optimization. - Acta Oecol. 14: 1-15.

Matthysen, E. 1989. Territorial and nonterritorial settling in juvenile Eurasian Nuthatches (Sitta europaea L.) in summer. - Auk 106: 560-567.

Matthysen, E. 1990.Non-breeding social organization in Parus. Current Ornithology. New York, Plenum Press.

McNamara, J.M., Houston, A.I. \& Lima, S.L. 1994. Foraging routines of small birds in winter $-\mathrm{a}$ theoretical investigation. - J. Avian Biology 25: 287-302.

Nilsson, J.A. \& Smith, H. 1988. Effects of dispersal date on winter flock establishment and social dominance in Marsh Tits Parus palustris. - $J$. Anim. Ecol. 57: 917-928.

Pravosudov, V.V. \& Lucas, J.R. 2001. A dynamic model of short-term energy management in small food-caching and non-caching birds. - Behav. Ecology 12: 207-218.

Pulliam, H.R. \& Caraco, T. 1984. Living in groups: Is there an optimal group size? Pp. 128-138 in Behavioural Ecology. An Evolutionary Approach.(Krebs, J.R. \& Davies, N.B. Eds.). Oxford, Blackwell Scientific Publications.

Rajala, M., Rätti, O. \& Suhonen, J. 2003. Age differences in the response of Willow Tits (Parus montanus) to conspecific alarm calls. - Ethology 109: 501-509.

Rohwer, S. \& Wingfield, J.C. 1981. A field study of social dominance, plasma levels of luteinizing hormones and steroid hormones in wintering Harris' sparrows. - Z. Tierpsychol. 57: 173-183.

Schubert, K.A., Mennill, D.J., Ramsay, S.M., Otter, K.A., Boag, P.T. \& Ratcliffe, L.M. 2007. Variation in social rank acquisition influences lifetime reproductive success in Black-capped Chickadees. - Biol.J. Linnean Society 90: 85-95.

Silverin, B., Viebke, P.-A. \& Westin, L. 1984. Plasma levels of luteinizing hormone and steroid hormones in free-living winter groups of Willow Tits (Parus montanus). - Hormones and Behavior 18: 367-379.

Suhonen, J. 1993a. Predation risk influences the use of foraging sites by tits. - Ecology 74: 1197-1203.

Suhonen, J. 1993b Risk of predation and foraging sites of individuals in mixed-species tit flocks. Anim. Behav. 45: 1193-1198.

Woolfenden, G.E. \& Fitzpatrick, J.W. 1978. The inheritance of territory in group-breeding birds. - Bioscience 28: 104-108.

Zanette, L. \& Ratcliffe, L.M. 1994. Social rank influences conspicuous behaviour of Blackcapped Chickadees, Parus atricapillus. Anim. Behav. 48: 119-127. 